\title{
Paenibacillus aestuarii sp. nov., isolated from an estuarine wetland
}

\author{
Jee-Yeon Bae, ${ }^{1}$ Ki-Yeon Kim, ${ }^{1}$ Ju-Hyoung Kim, ${ }^{1}$ Kangseok Lee, ${ }^{2}$ \\ Jang-Cheon $\mathrm{Cho}^{3}$ and Chang-Jun Cha ${ }^{1}$ \\ ${ }^{1}$ Department of Biotechnology, Chung-Ang University, Anseong 456-756, Republic of Korea \\ ${ }^{2}$ Department of Life Science, Chung-Ang University, Seoul 156-756, Republic of Korea \\ ${ }^{3}$ Department of Biology and Ocean Sciences, Inha University, Incheon 402-751, Republic of Korea
}

\author{
Correspondence \\ Chang-Jun Cha \\ cjcha@cau.ac.kr
}

\begin{abstract}
A novel bacterial strain designated $\mathrm{CJ} 25^{\top}$ was isolated from the estuarine wetland of the Han river in Korea. Identification of this strain was carried out on the basis of polyphasic taxonomy. The isolate was Gram-staining-positive, rod-shaped, non-pigmented and motile. Phylogenetic analysis based on the 16S rRNA gene sequence revealed that the isolate was closely related to Paenibacillus chondroitinus DSM $5051^{\top}$ with $96.1 \%$ similarity. The predominant fatty acids were anteiso- $\mathrm{C}_{15: 0}(50.25 \%)$, iso- $\mathrm{C}_{16: 0}(18.54 \%)$ and iso- $\mathrm{C}_{15: 0}(10.00 \%)$. The major isoprenoid quinone was MK-7. The $\mathrm{G}+\mathrm{C}$ content of genomic DNA was $50 \mathrm{~mol} \%$. According to physiological data and 16S rRNA gene sequence analysis, the isolate was discriminated from related members of the genus Paenibacillus. Therefore, strain $\mathrm{CJ} 25^{\top}$ represents a novel species of the genus Paenibacillus, for which the name Paenibacillus aestuarii sp. nov. is proposed. The type strain is $\mathrm{CJ}_{2} 5^{\top}\left(=\right.$ KACC $\left.13125^{\top}=\mathrm{JCM} 15521^{\top}\right)$.
\end{abstract}

The genus Paenibacillus is a diverse group of bacteria that are commonly found in soil and estuarine wetlands and comprises 99 species with validly published names at the time of writing (DSMZ, http://www.dsmz.de/). The estuarine wetlands of the Han river have been regarded as contaminated environments where large amounts of industrial wastewater and sewage accumulate in the river ( $\mathrm{Li}$ et al., 2004). As microbial diversity in this environment is expected to be exceptionally high, we tried to isolate bacteria capable of degrading hazardous pollutants such as polycyclic aromatic hydrocarbons. During the enrichment culture, a Paenibacillus-like bacterium was isolated and characterized. In this study, we report the description of a novel species of the genus Paenibacillus, which showed low $16 \mathrm{~S}$ rRNA gene sequence similarity to all recognized species of this genus.

A bacterial strain designated CJ $25^{\mathrm{T}}$ was isolated from the estuarine wetland of the Han river, South Korea. Enrichment culture was performed using pyrene as a sole carbon source in a minimal medium that contained: $0.5 \mathrm{~g}$ $\mathrm{NaNO}_{3}, 1.0 \mathrm{~g}\left(\mathrm{NH}_{4}\right)_{2} \mathrm{SO}_{4}, 2.5 \mathrm{~g} \mathrm{KH}_{2} \mathrm{PO}_{4}, 1.0 \mathrm{~g} \mathrm{Na}_{2} \mathrm{HPO}_{4}$, $0.03 \mathrm{~g} \mathrm{CaCl}_{2}, 0.02 \mathrm{~g} \mathrm{MgCl}_{2}$ and $1 \mathrm{ml}$ trace element solution (containing $1.94 \mathrm{~g} \mathrm{Al}_{2}\left(\mathrm{SO}_{4}\right)_{3} .18 \mathrm{H}_{2} \mathrm{O}, 1.0 \mathrm{~g} \mathrm{CoSO}_{4} .7 \mathrm{H}_{2} \mathrm{O}$, $1.0 \mathrm{~g} \mathrm{CuSO}_{4} .5 \mathrm{H}_{2} \mathrm{O}, 54 \mathrm{~g} \mathrm{FeSO}_{4} .7 \mathrm{H}_{2} \mathrm{O}, 11.0 \mathrm{~g} \mathrm{H}_{3} \mathrm{BO}_{3}, 0.5 \mathrm{~g}$

The GenBank/EMBL/DDBJ accession number for the 16S rRNA gene sequence of strain $\mathrm{CJ}^{\mathrm{T}} 5^{\mathrm{T}}$ is EU570250.

An extended phylogenetic tree is available with the online version of this paper.
$\mathrm{KBr}, 0.5 \mathrm{~g} \mathrm{LiCl}, 1.0 \mathrm{~g} \mathrm{KI}, 7.0 \mathrm{~g} \mathrm{MnCl}_{2} .4 \mathrm{H}_{2} \mathrm{O}, 0.5 \mathrm{~g}$ $\mathrm{Na}_{2} \mathrm{MoO}_{4} .2 \mathrm{H}_{2} \mathrm{O}, 0.5 \mathrm{~g} \mathrm{Na}_{2} \mathrm{WO}_{4} .2 \mathrm{H}_{2} \mathrm{O}, 1.0 \mathrm{~g} \mathrm{NiCl}_{2} .6 \mathrm{H}_{2} \mathrm{O}$, $0.5 \mathrm{~g} \mathrm{SnCl}_{2} \cdot 2 \mathrm{H}_{2} \mathrm{O}$ and $0.62 \mathrm{~g} \mathrm{ZnSO}_{4} \cdot \mathrm{H}_{2} \mathrm{O}$ in a total volume of $18 \mathrm{l}$ ) per litre distilled water. During cultivation, spreading and selection of colonies were carried out on R2A agar (Difco). The isolate was routinely cultured in R2A broth at $30{ }^{\circ} \mathrm{C}$ and maintained as a glycerol suspension $(30 \%, \mathrm{w} / \mathrm{v})$ at $-80{ }^{\circ} \mathrm{C}$. Anaerobic atmosphere was prepared by using a BD GasPak pouch (Becton Dickinson) for anaerobic growth. Growth was tested at different temperatures $\left(4-50{ }^{\circ} \mathrm{C}\right)$ and $\mathrm{pH}(2.0-10.0$ at $1 \mathrm{pH}$ unit intervals, adjusted by adding $\mathrm{HCl}$ or $\mathrm{NaOH}$; Takeda et al., 2005). Growth was generally monitored by measuring optical density at $600 \mathrm{~nm}$. Motility was tested on semisolid R2A media containing $0.4 \%$ agar (Smibert \& Krieg, 1994). Growth occurred at $20-37^{\circ} \mathrm{C}$ and at $\mathrm{pH} 5-$ 10. Optimal growth temperature and $\mathrm{pH}$ ranges of the strain were $30-37{ }^{\circ} \mathrm{C}$ and $\mathrm{pH} 6-8$, respectively. Growth occurred in the presence of $0-10 \% \mathrm{NaCl}$ with an optimum of $0-1 \%$. Although the strain was isolated during enrichment culture for pyrene-degrading bacteria, degradation of pyrene was not observed. Additional growth properties of strain $\mathrm{CJ} 25^{\mathrm{T}}$ are summarized in the species description.

The 16S rRNA gene was amplified by PCR using AccuPower PCR Premix (Bioneer) that contained DNA polymerase, dNTPs, Tris/HCl ( $\mathrm{pH} 9.0), \mathrm{KCl}, \mathrm{MgCl}_{2}$, tracking dye and primers pBact27F (5'-AGAGTTTGATCMTGGCTCAG-3') and pUniv 1492R (5'-GGYTA- 
CCTTGTTACGACTT-3') (Lane, 1991). Purification of the PCR product from agarose gel was performed using a Rapid Gel Extraction kit (TAKARA). Sequencing of the 16S rRNA gene was performed at Solgent corp. (Daejeon, South Korea). The results of 16S rRNA gene sequencing were analysed using the EzTaxon server (http://www. eztaxon.org/; Chun et al., 2007). Phylogenetic analyses were performed by using the neighbour-joining (Saitou \& Nei, 1987), maximum-likelihood (Felsenstein, 1981) and maximum-parsimony (Fitch, 1971) methods. Evolutionary distance matrices for the neighbour-joining method were generated according to the model of Jukes \& Cantor (1969). The neighbour-joining tree topology was evaluated by bootstrap analyses (Felsenstein, 1985) based on 1000 resamplings. The phylogenetic tree was reconstructed using the MEGA4 (Tamura et al., 2007) and PHYLIP (Felsenstein, 2005) programs. According to $16 \mathrm{~S}$ rRNA gene sequence analyses, isolate $\mathrm{CJ} 25^{\mathrm{T}}$ showed the highest $16 \mathrm{~S}$ rRNA gene sequence similarity with Paenibacillus chondroitinus DSM $5051^{\mathrm{T}}(96.2 \%)$, followed by Paenibacillus larvae subsp. larvae DSM $7030^{\mathrm{T}}(95.6 \%)$, Paenibacillus chitinolyticus IFO $15660^{\mathrm{T}}(95.5 \%)$ and Paenibacillus alginolyticus DSM $5050^{\mathrm{T}}$ $(95.5 \%)$. In the phylogenetic tree, strain CJ $25^{\mathrm{T}}$ represented a distinct phyletic line corresponding to a novel species in the genus Paenibacillus (Fig. 1). For an extended phylogenetic tree, see Supplementary Fig. S1 in IJSEM Online.

Catalase activity was evaluated by assessing the production of $\mathrm{O}_{2}$ bubbles in a $3 \%(\mathrm{v} / \mathrm{v})$ aqueous $\mathrm{H}_{2} \mathrm{O}_{2}$ solution ( $\mathrm{Lim}$ et al., 2006). Oxidase activity was tested by assessing the oxidation of $1 \%(\mathrm{w} / \mathrm{v})$ tetramethyl-p-phenylenediamine (Merck). Citrate utilization was tested by using Simmons' citrate agar. Hydrolysis of casein was tested as described by Smibert \& Krieg (1994). Starch hydrolysis was tested using R2A with iodine. Carbon source utilization was determined by using the API ZYM, API 50CHB and API 20NE galleries according to the instructions of the manufacturer (bioMérieux). Biochemical and physiological properties are presented in Table 1 and in the species description.

Chemotaxonomic characteristics were determined from cells grown on R2A agar at $30{ }^{\circ} \mathrm{C}$ for 2 days. Isoprenoid quinones were extracted and purified as described by Minnikin et al. (1984) and preparations dried under nitrogen gas were dissolved in $200 \mu \mathrm{l}$ acetone; samples were analysed by HPLC (Varian) as described by Collins (1985) using a SYNERGI $4 \mu$ Hydro-RP column $(150 \times 4.60 \mathrm{~mm})$. Strain $\mathrm{CJ} 25^{\mathrm{T}}$ contained menaquinone 7 as the major quinone. Genomic DNA for $\mathrm{G}+\mathrm{C}$ content analysis was isolated using a Wizard genomic DNA purification kit (Promega). DNA G $+\mathrm{C}$ content was determined by the method of Mesbah et al. (1989) and analysed by HPLC (Varian) using a Supelcosil LC-18-S column. Experiments were performed in triplicate and the calculated $\mathrm{G}+\mathrm{C}$ content was $50 \mathrm{~mol} \%$. Fatty acid methyl ester analysis was carried out by GLC according to the instructions of the Microbial Identification system (MIDI; Microbial ID). The fatty acid profiles of strain $\mathrm{CJ} 25^{\mathrm{T}}$ and related taxa are presented in Table 2 . The major fatty acids for strain CJ $25^{\mathrm{T}}$ were anteiso- $\mathrm{C}_{15: 0}(50.25 \%)$ and iso- $\mathrm{C}_{16: 0}(18.54 \%)$, which was consistent with type strains of closely related species. Unlike the reference strains compared in Table 2, iso- $\mathrm{C}_{15: 0}(10.00 \%)$ was relatively high and unsaturated fatty acids were not detected in strain $\mathrm{CJ} 25^{\mathrm{T}}$.

As shown by the 16S rRNA gene sequence analysis, strain $\mathrm{CJ} 25^{\mathrm{T}}$ formed an independent phyletic line among recognized species of the genus Paenibacillus. Data from the polyphasic taxonomy study also differentiated the strain from related members of this genus. Therefore, we propose that strain $\mathrm{CJ} 25^{\mathrm{T}}$ be classified as the type strain of a novel species in the genus Paenibacillus, with the name Paenibacillus aestuarii sp. nov.

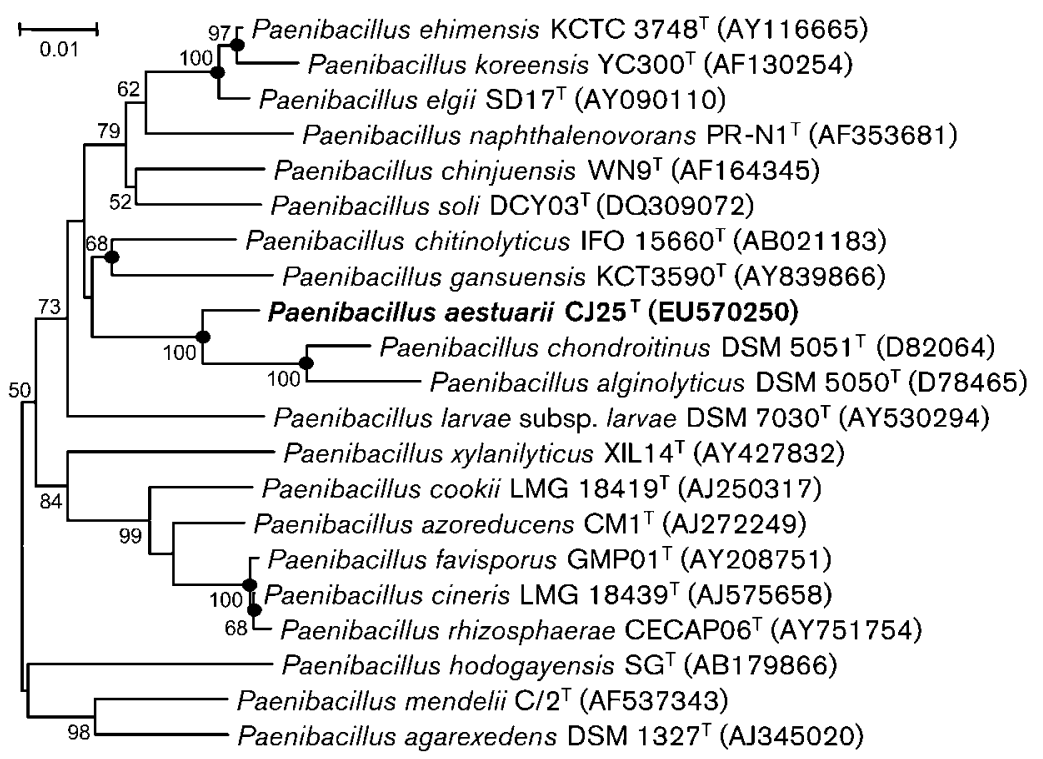

Fig. 1. Neighbour-joining tree showing the phylogenetic positions of strain $\mathrm{CJ} 25^{\top}$ and other related species of the genus Paenibacillus. Bootstrap values greater than $50 \%$ are shown at branch points based on neighbour-joining analyses of 1000 resampled datasets. Solid circles indicate that the corresponding nodes are also recovered in trees generated by the maximum-likelihood and maximum-parsimony algorithms. The tree is rooted using Bacillus subtilis as an outgroup. Bar, 0.01 nucleotide substitutions per position. 
Table 1. Differential characteristics of strain $\mathrm{CJ}_{2} 5^{\top}$ and related members of the genus Paenibacillus.

Strains: 1 , Paenibacillus aestuarii sp. nov. $\mathrm{CJ}^{2} 5^{\mathrm{T}} ; 2$, P. chondroitinus DSM $5051^{\mathrm{T}}$; 3, P. chitinolyticus IFO $15660^{\mathrm{T}} ; 4$, P. gansuensis KCTC $3950^{\mathrm{T}}$; 5, P. alginolyticus CIP $103122^{\mathrm{T}}$. DNA G $+\mathrm{C}$ content data are from Nakamura (1987), Kuroshima et al. (1996) and Lim et al. (2006). All strains are motile with swollen sporangia and are negative for oxidase, nitrate reduction, indole production and hydrolysis of gelatin. + , Positive; - , negative.

\begin{tabular}{|lccccc|}
\hline Characteristic & $\mathbf{1}$ & $\mathbf{2}$ & $\mathbf{3}$ & $\mathbf{4}$ & $\mathbf{5}$ \\
\hline Anaerobic growth & - & + & + & - & + \\
Optimum growth temp. & $30-37$ & 30 & 37 & $30-37$ & 30 \\
$\quad\left({ }^{\circ} \mathrm{C}\right)$ & - & + & + & - & + \\
Catalase & - & + & - & - & - \\
Urease & - & - & - & - & + \\
Citrate utilization & & & & & \\
Acid production from: & + & + & - & + & + \\
L-Arabinose & + & + & - & - & + \\
$\quad$ D-Mannitol & + & + & - & + & + \\
$\quad$ D-Xylose & + & + & - & + & - \\
Lactose & + & + & + & + & - \\
Maltose & - & + & + & + & - \\
$\quad$ D-Mannose & & & & & \\
Hydrolysis of: & + & + & - & + & + \\
Starch & - & - & + & + & - \\
Casein & 50 & $47-48$ & $51-53$ & 50 & $47-49$ \\
DNA G + C content & & & & & \\
(mol\%) & & & &
\end{tabular}

\section{Description of Paenibacillus aestuarii sp. nov.}

Paenibacillus aestuarii (aes.tu.a'ri.i. L. gen. n. aestuarii of a wetland, from where the type strain was isolated)

Cells are Gram-staining-positive, rod-shaped and motile. Growth occurs only under aerobic conditions. Colonies on R2A agar are circular and non-pigmented. Ellipsoidal spores are produced in swollen sporangia. Optimal growth at $30-37^{\circ} \mathrm{C}$ and at $\mathrm{pH} 6-8$. Catalase- and oxidase-negative. Nitrate is not reduced to nitrite. Citrate is not utilized. Indole is not produced. Starch is hydrolysed but gelatin and casein are not hydrolysed. $\beta$-Galactosidase, esterase, esterase lipase, leucine arylamidase, cystine arylamidase and naphthol-AS-BI-phosphohydrolase activities are present but urease, arginine dihydrolase, alkaline phosphatase, lipase, valine arylamidase, trypsin, $\alpha$-chymotrypsin, acid phosphatase, $\beta$-glucuronidase, $\alpha$-glucosidase, $\beta$-glucosidase, $N$-acetyl- $\beta$-glucosaminidase, $\alpha$-mannosidase and $\alpha$ fucosidase activities are absent. Acid is produced from the following substrates: L-arabinose, D-xylose, methyl $\beta$-Dxylopyranoside, D-galactose, D-glucose, D-mannitol, methyl $\alpha$-D-glucopyranoside, amygdalin, aesculin, salicin, cellobiose, D-maltose, lactose, melibiose, D-sucrose, D-trehalose, D-raffinose, starch, glycogen, xylitol, gentiobiose, D-turanose, D-lyxose, D-tagatose and 5-keto-gluconate. Acid is not produced from the following substrates: glycerol, erythritol, D-arabinose, D-ribose, L-xylose, D-adonitol, D-
Table 2. Cellular fatty acid profiles of strain $\mathrm{CJ}_{25}{ }^{\top}$ and type strains of related species of the genus Paenibacillus

Strains: 1 , Paenibacillus aestuarii sp. nov. $\mathrm{CJ} 25^{\mathrm{T}} ; 2$, P. chondroitinus DSM $5051^{\mathrm{T}} ; 3$, P. chitinolyticus IFO $15660^{\mathrm{T}} ; 4$, P. gansuensis KCTC $3950^{\mathrm{T}}$; 5, P. alginolyticus CIP $103122^{\mathrm{T}}$. Values are percentages of total fatty acids. - , Not detected.

\begin{tabular}{|lccccc|}
\hline Fatty acid & $\mathbf{1}$ & $\mathbf{2}$ & $\mathbf{3}$ & $\mathbf{4}$ & $\mathbf{5}$ \\
\hline Saturated fatty acids & & & & & \\
$\mathrm{C}_{14: 0}$ & 1.05 & 1.09 & 2.15 & 0.95 & 0.75 \\
$\mathrm{C}_{15: 0}$ & 0.56 & 2.70 & - & - & - \\
$\mathrm{C}_{16: 0}$ & 6.29 & 5.22 & 9.18 & 5.32 & 4.39 \\
$\mathrm{C}_{17: 0}$ & - & - & - & 0.44 & 0.10 \\
$\mathrm{C}_{18: 0}$ & 0.24 & 0.22 & 0.33 & 0.30 & - \\
Unsaturated fatty acids & & & & & \\
$\mathrm{C}_{16: 1} \omega 7 c$ alcohol & - & - & 0.39 & 0.49 & 0.19 \\
$\mathrm{C}_{16: 1} \omega 11 c$ & - & - & 2.68 & 1.49 & 0.22 \\
$\mathrm{C}_{18: 1} \omega 9 c$ & - & 0.32 & 0.27 & 0.34 & 0.21 \\
Branched fatty acids & & & & & \\
anteiso- $\mathrm{C}_{13: 0}$ & - & - & 0.26 & - & - \\
iso- $\mathrm{C}_{14: 0}$ & 7.77 & 4.94 & 1.56 & 2.80 & 2.25 \\
iso- $\mathrm{C}_{15: 0}$ & 10.00 & 2.44 & 3.50 & 2.90 & 3.11 \\
anteiso- $\mathrm{C}_{15: 0}$ & 50.25 & 66.22 & 65.42 & 67.62 & 69.65 \\
iso- $\mathrm{C}_{16: 0}$ & 18.54 & 14.98 & 5.09 & 10.13 & 12.2 \\
iso- $\mathrm{C}_{17: 0}$ & 1.65 & 0.48 & 1.33 & 0.76 & 0.73 \\
anteiso- $\mathrm{C}_{17: 0}$ & 3.19 & 3.53 & 6.67 & 5.63 & 5.06 \\
iso- $\mathrm{C}_{17: 1} \omega 10 c$ & - & - & 0.15 & - & - \\
& & & & & \\
\hline
\end{tabular}

fructose, D-mannose, L-sorbose, L-rhamnose, dulcitol, inositol, D-sorbitol, methyl $\alpha$-D-mannopyranoside, $N$ acetylglucosamine, arbutin, inulin, D-melezitose, D-fucose, L-fucose, D-arabitol, L-arabitol, gluconate or 2-keto-gluconate. The major quinone is MK-7. The predominant fatty acids are anteiso- $\mathrm{C}_{15: 0}$, iso- $\mathrm{C}_{16: 0}$ and iso- $\mathrm{C}_{15: 0}$. The DNA $\mathrm{G}+\mathrm{C}$ content of the type strain is $50 \mathrm{~mol} \%$.

The type strain is CJ $25^{\mathrm{T}}\left(=\mathrm{KACC} 13125^{\mathrm{T}}=\mathrm{JCM} 15521^{\mathrm{T}}\right)$, isolated from the sediment of the estuarine wetland of the Han river, South Korea.

\section{Acknowledgements}

This research was supported by the Chung-Ang University Research Scholarship Grants in 2008.

\section{References}

Chun, J., Lee, J.-H., Jung, Y., Kim, M., Kim, S., Kim, B. K. \& Lim, Y. W. (2007). EzTaxon: a web-based tool for the identification of prokaryotes based on $16 \mathrm{~S}$ ribosomal RNA gene sequence. Int J Syst Evol Microbiol 57, 2259-2261.

Collins, M. D. (1985). Analysis of isoprenoid quinones. Methods Microbiol 18, 329-366.

Felsenstein, J. (1981). Evolutionary trees from DNA sequences: a maximum likelihood approach. J Mol Evol 17, 368-376.

Felsenstein, J. (1985). Confidence limits on phylogenies: an approach using the bootstrap. Evolution 39, 783-791. 
Felsenstein, J. (2005). PHYLIP (phylogeny inference package), version 3.6. Distributed by the author. Department of Genome Sciences, University of Washington, Seattle, USA.

Fitch, W. M. (1971). Toward defining the course of evolution: minimum change for a specific tree topology. Syst Zool 20, 406-416.

Jukes, T. H. \& Cantor, C. R. (1969). Evolution of protein molecules. In Mammalian Protein Metabolism, vol. 3, pp. 21-132. Edited by H. N. Munro. New York: Academic Press.

Kuroshima, K., Sakane, T., Takata, R. \& Yokota, A. (1996). Bacillus ehimensis sp. nov. and Bacillus chitinolyticus sp. nov., new chitinolytic members of the genus Bacillus. Int J Syst Bacteriol 46, 76-80.

Lane, D. J. (1991). 16S/23S rRNA sequencing. In Nucleic Acid Techniques in Bacterial Systematics, pp. 115-175. Edited by E. Stackebrandt \& M. Goodfellow. Chichester: Wiley.

Li, D., Kim, M., Shim, W. J., Yim, U. H., Oh, J. R. \& Kwon, Y.-J. (2004). Seasonal flux of nonylphenol in Han River, Korea. Chemosphere 56, 1-6.

Lim, J.-M., Jeon, C. O., Lee, J.-C., Xu, L.-H., Jiang, C.-L. \& Kim, C.-J. (2006). Paenibacillus gansuensis sp. nov., isolated from desert soil of Gansu Province in China. Int J Syst Evol Microbiol 56, 2131-2134.

Mesbah, M., Premachandran, U. \& Whitman, W. B. (1989). Precise measurement of the $\mathrm{G}+\mathrm{C}$ content of deoxyribonucleic acid by high-performance liquid chromatography. Int J Syst Bacteriol 39, 159167.

Minnikin, D. E., O’Donnell, A. G., Goodfellow, M., Alderson, G., Athayle, M., Schaal, A. \& Parlett, J. H. (1984). An integrated procedure for the extraction of isoprenoid quinones and polar lipids. J Microbiol Methods 2, 233-241.

Nakamura, L. K. (1987). Bacillus alginolyticus sp. nov and Bacillus chondroitinus sp. nov., two alginate-degrading species. Int J Syst Bacteriol 37, 284-286.

Saitou, N. \& Nei, M. (1987). The neighbor-joining method: a new method for reconstructing phylogenetic trees. Mol Biol Evol 4, 406425.

Smibert, R. M. \& Krieg, N. R. (1994). Phenotypic characterization. In Methods for General and Molecular Bacteriology, pp. 607-654. Edited by P. Gerhart, R. G. E. Murray, W. A. Wood \& N. R. Krieg. Washington, DC: American Society for Microbiology.

Takeda, M., Suzuki, I. \& Koizumi, J. (2005). Paenibacillus hodogayensis sp. nov., capable of degrading the polysaccharide produced by Sphaerotilus natans. Int J Syst Evol Microbiol 55, 737-741.

Tamura, K., Dudley, J., Nei, M. \& Kumar, S. (2007). MEGA4: molecular evolutionary genetics analysis (MEGA) software version 4.0. Mol Biol Evol 24, 1596-1599. 